\title{
Determinants of Smallholder Farmers Participation in Formal Credit and Challenges Faced by Institutions: The Case of Mojana Wodera District, Amhara Region, Ethiopia
}

\author{
Woleteyes Mamuye \\ Department of Agricultural Economics, Ambo University, Ambo, Ethiopia
}

Email address:

wellmamo07@gmail.com

\section{To cite this article:}

Woleteyes Mamuye. Determinants of Smallholder Farmers Participation in Formal Credit and Challenges Faced by Institutions: The Case of Mojana Wodera District, Amhara Region, Ethiopia. International Journal of Finance and Banking Research. Vol. 7, No. 1, 2021, pp. 9-20. doi: $10.11648 /$ j.ijfbr.20210701.12

Received: December 28, 2020; Accepted: January 20, 2021; Published: March 10, 2021

\begin{abstract}
Agricultural finance for smallholder farmers is critical for the growth and development of agricultural sector. Despite the increasing number of formal financial institutions penetrating in rural areas of Ethiopia, access to credit among the majority of agricultural households remains limited. To ensure that appropriate strategies are designed for improving participation in formal credit, it is important to understand why smallholder farmers cannot borrow loan for farming purposes from formal sources. Thus, this study was sought to ascertain factors that affect smallholder farmers participation in formal credit and challenges of formal financial institutions lending to agricultural activities (smallholders). Structured interview was used for collecting the data from the sampled farm households. Descriptive statistics and binary logit model were used for analyzing data. The study indicates that $43(31.16 \%)$ of the sampled farm households were formal credit participants, whereas the remaining 95 (68.84\%) were non-participants. Negative perception of farm households in formal credit participation was attributed the isolation of very poor farmers from group formation in case of group lending system. Number of livestock owned, group lending and distance from lending institution were factors influencing participation of households in formal credit use negatively as evidenced by the model output. This study recommends that in order to make agricultural development successful these factors and problems are taken into consideration by policy makers to enable participation in credit use from formal financial sources.
\end{abstract}

Keywords: Binary Logit Model, Formal Credit, Smallholder, Participation, Challenges

\section{Introduction}

\subsection{Background of the Study}

As in other developing countries, Access to credit is considered as one of the key elements in achieving the transformation plan in Ethiopia and is an important factor in economic development to achieve higher growth in agricultural sector. In developing countries, lack of credit constitutes a critical constraint to adoption, use of improved inputs and modern technologies of farming. It is widely acknowledged that inadequate financial resources are a key constraint to farmers' investments in enhancing agricultural productivity [1].

It is also becoming increasingly important to the livelihood of smallholders by generating additional activity and creating new jobs. Limited participation of rural households in formal credit has been implicated as a hindrance to the growth and productivity of the agricultural sector [2].

Recently government of Ethiopia gave more emphasis for the development of financial institutions in the country to address the problem of credit participation in rural areas. As a result several microfinance institutions (MFIs) have been established and operating towards resolving the credit participation problem of the rural poor [3]. By the end of 2017, the number of microfinance institutions (MFIs) operating in the country reached 34 . Their overall performance was encouraging as their saving deposit and total asset increased by 28.7 and 24 percent and reached Birr 22.7 billion and Birr 43 billion respectively [4]. 
Mojana Wodera Woreda under consideration is characterized by factors such as poor infrastructure, backward farming, poor living standard, high rate of unemployment, limited participation in formal financial market and low capital formation which leads to low productivity. The poor people who do not have capital to buy enough fertilizers and those who do not use other technological inputs for agricultural production produce less compared to others.

\subsection{Statement of the Problem}

Credit provision is one of the principal components of rural development, which helps to attain rapid and sustainable growth of agriculture. However, Smallholder farmers living under the poverty line with limited participation in formal credit markets are excluded from enjoying the benefits of modern technology. The formal financial sectors in Ethiopia have inadequate inclusion of the rural areas [5]. This is because of the existence of group lending system to solve the problem of collateral had not been addressed.

Formal microfinance institution establishing distribution networks and branches in rural areas remain costly and unattractive. According to Mix market [6] currently in Amhara Credit and Saving Institution (ACSI) there are about 975,104 active credit clients. It is only $12-15 \%$ of demand taking only the number of the very poor. Some farmers try to fulfill their demand by informal lenders and there are many other economically active poor people still who have not got credit service So, it is important to identify and address both supply and demand side constraints (challenges) if smallholders have to effectively demand for, access and benefit from institutional credit.

To narrow the gap between owned and required capital rural farm households have been accessing credit from financial institutions. In addition, the study district is known for its high amount of inputs, technology and high labor use during peak periods of harvesting and weeding which requires capital. However, only $31 \%$ of the populations have participated in formal financial institution and determinants of households' participation in formal credit are not determined in the study area [7]. So, this has to be empirically studied as it helps specifically to improve participation of smallholder farmers in formal credit. On account of this background, this study was undertaken to fill the information gap on the factors affecting smallholder farmers' participation in formal credit in Mojana Wodera District. Because, lack of participation of smallholder farmers in formal credit market has been a challenge in Ethiopia in general and in the study district in particular.

\subsection{Objectives of the Study}

\subsubsection{General objective}

The general objective of this study was to investigate factors influencing smallholder farmers' participation in formal credit and the challenges that the institution faces in

\section{Mojana Wodera District.}

\subsubsection{Specific objectives}

Specifically, it was intended to:

1. Identify the challenges of formal financial institutions lending for smallholder farmers.

2. Investigate factors that influence smallholder farmers' participation in formal credit in the study area.

\subsection{Significance of the Study}

This study was expected to have a great significance for smallholders in the district, who are suffering from lack of credit for immediate operation and solve challenges of participation for them. it is also important to policy makers, financers and government in providing information that will enable to take effective measures by lending and policy makers to improve smallholder farmers' participation in formal credit. It can also be used by universities and NGOs as a reference material.

\section{Literature Review}

\subsection{Theoretical Overview}

The Structure of Agricultural and Rural Financial Services

Agricultural finance refers to financial services including savings, transfers, insurance and loans, potentially needed by the agricultural sector meaning farming and farm-related activities including input supply, processing, wholesaling, and marketing. Most of these activities are conducted in rural areas. But, large processing facilities and agribusinesses as well as (many) largely subsistence-level smallholders are also located in urban and peri-urban areas [8].

\subsection{Types of Rural Credit}

Rural credit institutions can be broadly characterized into formal institution and informal institutions. Formal institutions are licensed and regulated by central banks. The informal sector is not regulated by any formal institution and the lending conditions are often flexible [9].

\subsubsection{Formal Financial Institutions in Ethiopia}

Ensuring adequate access to credit to farmers is a key tenet of successful rural development strategies. Policy-makers have long understood that rural producers who cannot meet their need for capital must settle for suboptimal production strategies. Furthermore, without adequate access to loans or insurance producers face negative shocks such as droughts, illness or a significant drop in the prices they receive and can lose some of the few assets they have [10].

As annual report of the NBE [4], notifies that the numbers of MFIs operating in the country have reached 34. Their overall performance was encouraging as their saving deposit and total asset increased by 28.7 and 24 percent and reached Birr 22.7 billion and Birr 43 billion, respectively.

The three largest microfinance institutions; Amhara credit and saving institute-ACSI, Dedebit credit and saving 
institute-DECSI and Oromia credit and saving-OCSSCO account for 65 percent of the market share in terms of borrowing clients and 74 percent by loan provision [11]. By having emphasis on the rural households poor farmers are being targeted since the main activity in the rural Ethiopia is agriculture.

As indicated by Getaneh [12], Amhara Credit and Saving Institution (ACSI) was established in the Amhara region and aims to fill the gap of formal institutions by meeting the needs of small scale borrowers in income generation schemes. It was initiated by the Organization for the Rehabilitation and Development in Amhara (ORDA) an indigenous NGO engaged in development activities in the Amhara region. Presently, ACSI is operating in all Woredas of the Region. Nevertheless, there are many economically active poor people still not covered by the service.

\subsubsection{Informal Credit Institutions in Ethiopia}

Dejene [13] found that the informal sources in Ethiopia include relatives and friends, moneylenders, neighbors, Iddir, Iqqub and Mahaber. According to this study the coverage of the sources of loans include friends and relatives ( 66 percent) moneylenders (14 percent) and Iddir (7 percent). In other words the bulk of the rural credit comes from informal sources. Every year the informal sector mobilizes resources equivalent to about 10 percent of deposits mobilized by all banks in Ethiopia.

The socio-economic base line survey in the Amhara region review that the most widely used financial institutions in rural areas were informal which provided very small loan size for short period and especially for daily consumption. The survey result indicates that from the total respondents about 65 percent of the households were accessing credits from informal institutions [11].

Generally, the status quo of the Ethiopian financial system is highly questionable. The problem becomes even worse in the rural parts of the country. Due to high probability of default of smallholders, formal financial institutions usually abstain themselves to deliver financial services. However, the ongoing recent microfinance revolution creates opportunity for smallholder farmers in rural areas; though one can easily notice that lack of liquidity is yet on top of problems in rural areas.

\subsection{Challenges of Formal Financial Institutions Lending to Agriculture}

In Africa in general and Ethiopia in particular, agriculture is yet the main sector of the economy in which the formal financial sector is not conspicuously successful in delivering financial services to farmers. In the continent, finance for agriculture and the rural economy in general is unable to meet the rising demand of farmers.

\subsection{Empirical Studies on Determinants of Participation in Formal Credit}

A number of factors explain why households' participation in formal credit is limited. According to Hussien [14] gender, education, extension visits, household labor and farm size increases the probability of using credit from formal credit sources.

Shah et al. [15] used a binary logistic regression model in identifying the factors affecting household access to credit and participation in credit programme in Pakistan. The study found that at household level, participation to credit was influenced by age of the head of household, years of schooling of household head, income earners in a household and household size positively.

Similarly, Gunnar [16] who stated that with the increase in age, accumulated experience, practical and professional wisdom of the household increased his/her income generating capability and he demanded more credit to explore his capabilities or to spend on consumption. So those variables influence participation of smallholders in formal credit positively.

Tang et al. [17] indicated education as one of important variables that affect households' demand for farm credit positively. In their finding it was possible to show that one additional year of education would increase the probability of borrowing by another 2.5 percent and doubling land endowment would increase the probability by 5.6 percent.

Duy [18] in a study in Vietnam, found that access to credit was positively related to a larger family with relatively more dependents and that households with larger landholding had a higher probability of borrowing. The study also found that personal characteristics such as level of education, marital status and involvement in village work were important factors which influence participation of smallholder farmers positively.

Similarly, Abdalla and Ebiadalla [19] found that participation of farmer in formal credit institution is positively influenced by family size, experience of the household head in credit use, ownership of adequate collateral and participation of the household head in training/extension activities. They also found that distance travelled by farmer to the lending institution negatively affect the access to formal credit institutions.

According to Lighton et al. [20] contact with extension services, attitude towards risk of borrowing and ownership of cultivated land significantly and positively influences participation in formal credit.

In Ethiopia, the study by Ali and Deininger [21] found that nonfarm income, number of oxen and value of livestock ownership are some of the factors influencing participation of smallholders in formal credit negatively.

Generally, there have been different determinants of credit participation presented differently by different authors that have been carried out within or outside Ethiopia in the literature. This allowed us to include more and additional variables which could affect credit participation of smallholders than some of the prior studies. Most of the researchers focused on the demand side factors responsible for limited participation in formal credit use. But, this study considered both demand and supply side factors (challenges) which are responsible for limited participation of 
smallholders in formal credit. For instance, this paper is the first in its kind to explain effectiveness of group lending system in the study area. Hence, based on the above explanations and the author's knowledge of the credit schemes of the study area the following conceptual framework depicted the most important variables expected to influence smallholder farmers' participation in formal credit in the study area.

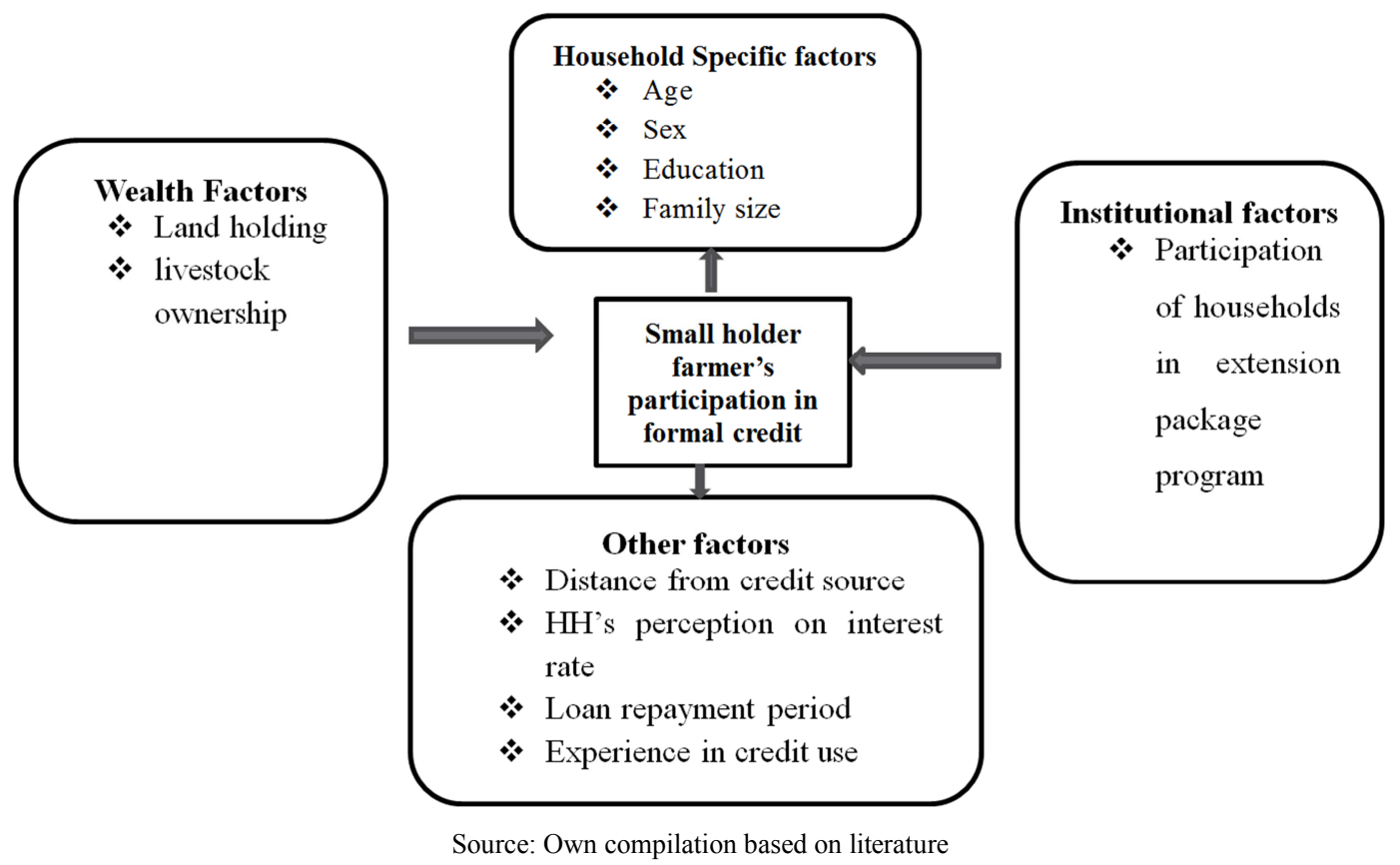

Figure 1. Conceptual framework on determinants of participation in formal credit.

\section{Research Methodology}

\subsection{Description of the Study Area}

\subsubsection{Location}

Mojana Wodera is one of the Woredas in Amhara National Regional State of Ethiopia; Part of Semen Showa Zone. Mojana Wodera is bordered on the South by Basona Werana, on the Northeast by Menz Lalo Midir, on the North by Menz Mam Midir, and on the East by Termaber. The administrative center of this Woreda is Seladingay. Mojana Wodera was located about $120 \mathrm{~km}$ Northwest of Addis Ababa. The altitude of Mojana Wodera ranges from as low as 550 to 1608 $\mathrm{m}$ above sea level and the rainy months extend from June to the end of September. Based on the 2007 national census conducted by the Central Statistical Agency of Ethiopia (CSA), this woreda has a total population of 69,667 , of which 35,186 are men and 34,481 women; 2,477 or $3.56 \%$ are urban inhabitants.

\subsubsection{Financial institutions}

Amhara Credit and Saving Institution (ACSI) is the major provider of formal credit and saving service for the rural population in the district. There are also many informal institutions in the district which give loan for smallholders in the form of cash and kind. The credit repayment schedule varies from one investment type to the other. The maximum loan period in ACSI is 1 year. ACSI also focuses more on encouraging people to save their money and rely on their own income.

\subsection{Sampling Method and Sample Size}

For this study; multi-stage sampling techniques were used. At the first stage, Mojana Wodera District was selected purposively. Secondly, four out of fourteen kebeles in the Woreda; namely: Birka, Ababersoma, Ganarada and Engidwasha were selected randomly. To select the representative respondents from each kebele, households in the selected kebeles were identified and stratified in to two strata: participants and non- participants in formal credit. Then, the sample respondents from each stratum were selecte" $\mathrm{d}$ randomly by using simple random sampling technique. Since the number of households in each Keble Administrations was not similar, probability proportional to size was used to determine the number of respondents from each stratum.

By applying Yamane [22] formula, 138 sampled households were selected at $95 \%$ confidence level, degree of variability of $=0.5$ and estimation of $8.5 \%$ margin of error.

$$
\mathrm{n}=\frac{N}{1+N(e) 2}=\frac{18546}{1+18546(0.085)^{2}}=\frac{18546}{135}=138
$$

Where $\mathrm{n}$ is the sample size, $\mathrm{N}$ is the population size (total households in the sampled kebeles), and $\mathrm{e}$ is the level of precision.

\subsection{Type and Sources of Data}

Both primary and secondary sources of data were major sources of the researcher. The primary source of data was 
questionnaire distributed to sample households. The secondary data include information that was obtained mainly from different reports, bulletins, websites and literatures which are relevant to the theme of the study. Amhara Credit and Saving Institution (ACSI) Mojana Mojana Wodera subbranch was also the major source of secondary data for this study.

\subsection{Method of Data Collection}

To collect relevant data from the selected samples a questionnaire which consist both open and closed ended questions was applied. In order to get a reliable data from respondents both structured and semi-structured questionnaires was prepared and administered to the target respondents. Secondary data was collected using reviewing and careful examination of documents, research reports, published and unpublished writings, different journals and internet websites.

\subsection{Methods of Data Analysis}

\subsubsection{Descriptive Analysis}

Descriptive statistics such as mean and percentage were used to describe the characteristics that can influence participation in formal credit use. In addition, mean comparison tools t-test for continuous variables and chi- square test for dummy variables were applied.

\subsubsection{Econometric Model}

Binary logistic regression model was applied in this study. This is because of the dependent variable is a dummy, which takes a value of zero or one depending on whether or not smallholder farmers participate in formal credit. where $1=$ participant and $0=$ non-participant. In addition, the marginal effect of each explanatory variable on the dependent variable preferred for model output interpretation of the study [23]. So, the complete econometric model specification for this study was expressed as follows: $\mathrm{Z}_{\mathrm{i}}=\alpha$ $+\beta_{1}$ age $+\beta_{2}$ sex $+\beta_{3}$ educ $+\beta_{4}$ famsize $+\beta_{5}$ partextpa + $\beta_{6}$ p_intrat $+\beta_{7}$ excrufs $+\beta_{8}$ farmsiz $+\beta_{9}$ livestock + $\beta_{10}$ p_glending $+\beta_{11}$ dinst $+\beta_{12}$ repperiod $+u_{i}$ Where: $Z$ is the response or dependent variable- smallholder farmer's participation in formal credit and explanatory variables were age, sex, educ, famsize, partexpa=, p_intrat, excrufs, farmsiz=Farm size in hectare, livestock, p_glending, dinst and repperiod.

$u_{i}$ is an error term and $\alpha$ is the intercept term- constant which would be equal to the mean if all slope coefficients are 0. $\beta_{1}, \beta_{2}, \beta_{3}, \beta_{4}, \beta_{5}, \beta_{6}, \beta_{7}, \beta_{8}, \beta_{9}, \beta_{10}, \beta_{11}$ and $\beta_{12}$ are the coefficients associated with each independent variable which measures the change in the mean value of $Z$, per unit change in their respective independent variables.

\subsection{Variables and Working Hypothesis}

Table 1. Summary of the variables and expected sign.

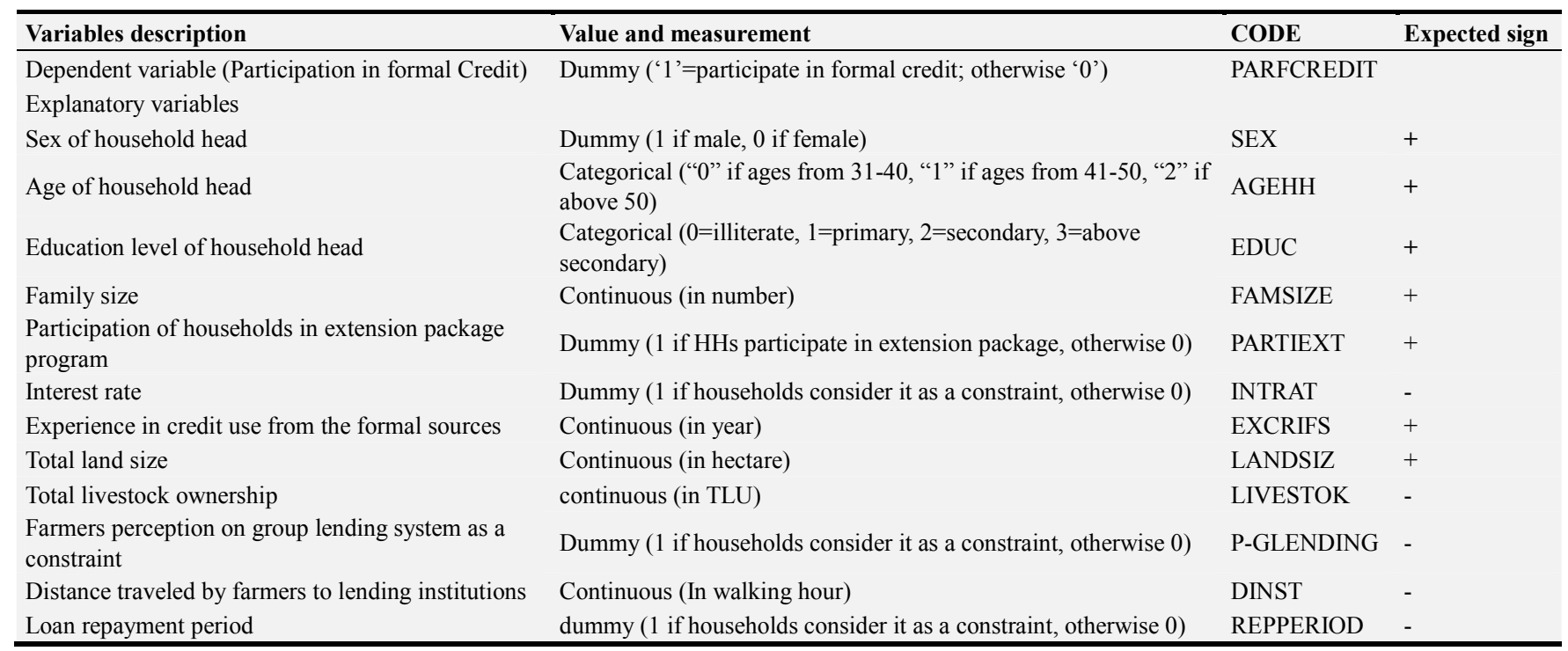

Source: Own processing

Table 2. Summary of descriptive statistical results for dummy (categorical) variables.

\begin{tabular}{|c|c|c|c|c|c|c|c|c|}
\hline \multirow{2}{*}{ Characteristics } & \multirow{2}{*}{ Categories } & \multicolumn{2}{|c|}{ Non participant } & \multicolumn{2}{|c|}{ Participant } & \multicolumn{2}{|c|}{ Total } & \multirow{2}{*}{$x^{2}$} \\
\hline & & $\mathbf{N}$ & $\%$ & $\mathbf{N}$ & $\%$ & $\mathbf{N}$ & $\%$ & \\
\hline \multirow{2}{*}{ Sex of household head } & Male & 59 & 62.11 & 32 & 74.42 & 91 & 78.26 & \multirow{5}{*}{1.09} \\
\hline & Female & 36 & 37.89 & 11 & 25.58 & 38 & 21.74 & \\
\hline \multirow{3}{*}{ Marital status } & Married & 73 & 76.8 & 40 & 93.02 & 113 & 81.88 & \\
\hline & Unmarried & 19 & 20 & 2 & 4.65 & 21 & 15.22 & \\
\hline & Separated & 3 & 3.16 & 1 & 2.33 & 4 & 2.89 & \\
\hline
\end{tabular}




\begin{tabular}{|c|c|c|c|c|c|c|c|c|}
\hline \multirow{2}{*}{ Characteristics } & \multirow{2}{*}{ Categories } & \multicolumn{2}{|c|}{ Non participant } & \multicolumn{2}{|c|}{ Participant } & \multicolumn{2}{|c|}{ Total } & \multirow{2}{*}{$x^{2}$} \\
\hline & & $\mathbf{N}$ & $\%$ & $\mathbf{N}$ & $\%$ & $\mathbf{N}$ & $\%$ & \\
\hline \multirow{4}{*}{ Age of household head in years } & $18-30$ & 21 & 22.1 & 0 & - & 21 & 15.22 & \multirow{4}{*}{$69.6 * * *$} \\
\hline & $31-40$ & 39 & 41.05 & 1 & 2.32 & 40 & 28.98 & \\
\hline & $41-50$ & 28 & 29.47 & 13 & 30.23 & 31 & 22.46 & \\
\hline & Above 50 & 6 & 6.32 & 30 & 69.77 & 36 & 26.09 & \\
\hline \multirow{3}{*}{ Education level of household head } & Illiterate & 49 & 29.47 & 22 & 51.16 & 71 & 51.45 & \multirow{3}{*}{2.07} \\
\hline & Primary & 44 & 70.53 & 18 & 41.86 & 62 & 44.93 & \\
\hline & Secondary & 2 & 2.13 & 3 & 6.98 & 5 & 3.62 & \\
\hline \multirow{2}{*}{ Participation in extension package program } & Yes & 35 & 36.84 & 10 & 23.26 & 45 & 32.61 & \multirow[t]{2}{*}{2.48} \\
\hline & No & 60 & 63.16 & 33 & 76.74 & 90 & 67.39 & \\
\hline \multirow{2}{*}{$\begin{array}{l}\text { Perception on group lending system as a constraint to } \\
\text { participate in formal credit }\end{array}$} & Yes & 84 & 89.47 & 11 & 23.27 & 95 & 68.84 & \multirow{2}{*}{$57.08 * * *$} \\
\hline & No & 11 & 11.58 & 32 & 74.42 & 43 & 31.16 & \\
\hline \multirow{2}{*}{$\begin{array}{l}\text { Farmers perception on interest rate as a constraint to } \\
\text { participate in formal credit }\end{array}$} & Yes & 12 & 12.63 & 21 & 48.87 & 33 & 21.91 & \multirow{2}{*}{2.88} \\
\hline & No & 83 & 87.37 & 22 & 51.16 & 105 & 78.09 & \\
\hline \multirow{2}{*}{$\begin{array}{l}\text { Perception on repayment period as a constraint to } \\
\text { participate in formal credit }\end{array}$} & Yes & 27 & 28.42 & 7 & 16.28 & 34 & 24.64 & \multirow{2}{*}{1.55} \\
\hline & No & 68 & 71.58 & 36 & 83.72 & 104 & 75.36 & \\
\hline
\end{tabular}

Source: Computed from the field survey data, 2018

\section{Result and Discussion}

\subsection{Descriptive Analysis on Characteristics of Sample Farm Households (For Dummy Variables)}

\subsubsection{Sex}

The sample was composed of $78.26 \%$ male headed households and $21.74 \%$ female headed households. This indicates gender of the household matters in determining the probability of being credit constraint. The implication is that male headed households had more participate in formal financial sources

\subsubsection{Marital Status}

About $81.88 \%$ of the sample households are married and the remaining are separated and unmarried. Of the total sample respondents 76.84 percent of non-participants and 93.02 percent of credit participants were married (Table 2). This implies that married households participate more in formal credit.

\subsubsection{Age of Household Head}

About $6.32 \%$ of non-participants and $69.77 \%$ of the participant households was above the age of 50. This implies that the higher the age of the household head increases the probability of households participating credit from formal sources. For example, in Pakistan, Shah et al. [15] found that participation in credit use was positively influenced by age of the household head. The chi-square test revealed that the difference between credit participants and non-participants with respect to age of household head was statistically significant at $1 \%$ significance level (Table 2).

\subsubsection{Education Level of Household Head}

About 44.93 and 3.62 percent of the sample households have attended primary and secondary school respectively, while 51.45 percent of the sample households were illiterate. Of the total sample respondents 29.47 percent of nonparticipants and 51.16 percent of participants were illiterate (Table 2). This may probably mean that most of the clients of the institution in the study area are illiterate.

\subsubsection{Participation in Extension Package}

The proportion of respondents who participated in the extension package program was only 32.61 percent. As the figures in Table 3 indicated, out of the total respondents, 36.84 percent from the non-participants and 23.61 percent from the credit participants have participated in agricultural extension package program. This was because farmers in the study area uses extensive farming system, fertilizer and other agricultural technologies are not widely used.

\subsection{Characteristics of Sample Farm Households (for Continuous Variables)}

Table 3. Summary of descriptive statistical result for continuous variables and t-test.

\begin{tabular}{|c|c|c|c|c|c|c|c|}
\hline \multirow{2}{*}{ Characteristics } & \multicolumn{2}{|c|}{ Non-Participant } & \multicolumn{2}{|c|}{ Participant } & \multicolumn{2}{|l|}{ Total } & \multirow{2}{*}{ t-test } \\
\hline & Mean & St. dev & Mean & St. dev & Mean & St. dev & \\
\hline Family size in number & 3.8 & 1.2 & 7.66 & 2.57 & 4.56 & 2.15 & $-27.09 * * *$ \\
\hline Total livestock in TLU & 31.9 & 20.13 & 12.98 & 13.25 & 30.67 & 22.89 & $15.42 * * *$ \\
\hline Land holding in hectare & 0.93 & 0.78 & 1.19 & 0.79 & 1.05 & 0.83 & $-9.6 * * *$ \\
\hline Experience in formal credit use & 0.65 & 0.94 & 2.44 & 2.16 & 1.14 & 1.63 & $-6.60 * * *$ \\
\hline Distance from organization in hour & 1.18 & 0.54 & 0.66 & 0.83 & 1.03 & 0.78 & $8.28 * * *$ \\
\hline
\end{tabular}

$* * *, * *, *$ represent level of significant at $1 \%, 5 \%$ and $10 \%$ probability level respectively.

Source: Computed from the field survey data, 2018 


\subsubsection{Family Size}

The result from t-test revealed that the mean difference between credit participants and non-participants with respect to family size was statistically significant at $10 \%$ probability level (Table 3). So, the level of participation of households in credit use determined by family size.

\subsubsection{Land Holding}

Based on the result of this study the average size of land owned by households was about 1.05 ha. The t-test revealed that the mean difference between the two groups (participant and non-participant households) with respect to land holding was statistically significant at 1\% significance level (Table 3) This could be because farmers with extra-large farm size need a large amount of credit due to the demand for agricultural inputs. Additionally, agricultural land is considered to be prominent collateral to obtain formal credit in rural areas.

\subsubsection{Livestock Ownership}

Farmers in the study area undertake both crop and livestock production activities. But, livestock holding size varied among the sample farmers. The mean livestock holding of the respondent farm households was 30.67 TLU. The minimum number of livestock maintained was 1 and the maximum was 86 TLU. Participants in in formal credit possessed relatively less livestock than non-participant households. The t-test revealed that the mean difference between the two groups (participant and non-participant households) with respect to total livestock ownership was statistically significant at 1\% significance level (Table 3 ).

\subsubsection{Experience in Formal Credit Use}

The average years of credit experience of sample households from the formal financial institutions in the study area were 1.14 years. Credit non-participants in formal source have an average experience of 0.6 years whereas the participants have an average year experience of 2.44 year (Table 3). By using $t$-test the mean difference between the participant and non-participant household heads in terms of experience of participation in formal credit was statistically significant at $1 \%$ significant level. This indicates a farmer having more experience in formal credit use will have higher tendency towards using the formal credit sources and vice versa.

\subsubsection{Distance Travelled by Farmers to Lending Institution}

The average walking hour of sample households to lending institution is 1 hour. The ent Period.

The repayment time for agricultural loans was immediately after crops are harvested. This implies that the repayment period is good for farmers if it is on harvesting time or when the farmers get income to repay their loan. But, most of the households pointed out that at the time of harvesting the price of crops reduced and unable to get more profit from their production in selling their crops to repay the loan. So, in the study area the repayment time (season) is not accepted by households to participate in formal credit. Otherwise, the loan duration of 1 year is appropriate and accepted by $76 \%$ of sample households.

\subsubsection{Farmers Perception on Interest Rate}

In the study area, ACSI charges an interest rate up to 19 percent from loan clients. Farmers have different perception of the amount of interest rates charged by the formal financial institutions. According to their view the level of interest charged by the institution is neither high nor low; they thought that it was reasonable. Therefore, the level of interest charged as compared to its service as perceived by farmers is justifiable because private moneylenders charge up to 100 per cent interest rate in the same place. But, they point out that the interest paid for their deposit lower than interest they paid for their loan. This discourages them to save in this institution.

\subsubsection{Farmers Perception on Group Lending System}

From the total sample households 89.47 percent of the non-participants and 23.27 percent of the participants responded that group lending was inconvenient to get credit from the formal sources. The difference between these figures was significant at $1 \%$ probability level (chisquare $=57.08$ ). This may be due to the fact that the better-off farmers do not want the poor in their group not to take risk in case of default.

In the study area, in the event that a member defaults, the group pays the loan on behalf of a defaulting member and if the group fails to repay the loan they will denied of future participation in credit use from the institution.

\subsubsection{Purpose of the Loan Sampled Participant Households Used}

Disaggregation of credit use shows that out of those who allocate the credit money for agricultural activities, the majority 15 (34.88\%) of sample households utilized the credit to cover household expenditure. while, $13(30.23 \%)$ households use it to start livestock production and 7 (16.28\%) for crop production.

Table 4. Purpose of the loan sampled participant farm households used.

\begin{tabular}{lll}
\hline Purpose the credit is used & $\mathbf{N}$ & $\mathbf{\%}$ \\
\hline Livestock production & 13 & 30.23 \\
Household expenditure & 15 & 34.88 \\
Crop production & 7 & 16.28 \\
Trading & 3 & 6.98 \\
Others & 5 & 11.63 \\
Total & 43 & 100 \\
\hline
\end{tabular}

Source: Computed from the field survey data, 2018

One of the reasons in this area in which households use their loan for consumption purpose rather than production purpose is the period that they get loan. Most of the time, they take loan in January. But, productive agricultural activities in the study area are seasonal and perform in the months June to December. Therefore, households use the loan for unintended and unproductive purpose because of the 
month of taking the loan is not working month for farmers. In addition, it leads to repayment problem due to the loan they take is unprofitable.

This result is consistent with the idea; smallholder farmers' main credit needs are for both production and consumption purposes. In addition, there is some evidence that smallholder farmers do save (in cash or in kind, particularly in livestock), mainly for future investment in agricultural activities, but firstly to fulfill their basic food needs [24].

\subsection{Challenges of Formal Financial Institution Lending to Smallholder Farmers}

As interview conducted with MWCSI officials and their source documents, the critical problems this woreda credit and saving institution faced were lack of awareness creation for the society on how they use credit, lack of group borrowing experience, poor infrastructure (higher transaction cost), lack of training opportunities to experts and farmers exposure to risk.

Lack of awareness creation for the society on how they use credit: this is the major problem of formal financial institutions in lending to smallholders. This is because of households in the study area use loan for consumption purpose rather than productive activities which makes them difficult to repay. So, the institution is not interested to lend for smallholder farmers.

A participatory rural appraisal conducted in Kenya by Musyimi [25] documented similar result that the majority of farmers had no access to credit due to lack of knowledge on how to get access and manage credit.

Lack of group borrowing experience: In the study area, households typically decline to participate in formal credit and they view the costs of participation are too high compared to the benefits. Moreover, poorest members might be excluded. Because, other members who are better off believe that the poor cannot utilize and pay credits on time.

Zeller et al. [26] showed that in formal credit programs, Smallholder farmers are expected to form a group (that can serve as collateral) to take credit from the formal credit sources. But, farmers perceived that group lending is difficult to participate in credit use from these sources. Households also incur time costs in compulsory training programs. There is also a time cost associated with screening, co-selecting and monitoring activities of group members in case of group lending.

Poor infrastructure (High transaction cost): this is one of the major challenges in the study area for both the institution and the clients to address the service. Similar to this result, Befkadu [27] found that smallholder farmers' decision making when requesting loans from formal banks, will depend more on the proportion of the borrowing costs to the households income, while financial institutions' willingness to lend to smallholder farmers will depend more on the magnitude of the costs on the institutional side. Therefore, MFIs have limited success in accessing the poorest of the poor and their underdeveloped infrastructure makes the provision of services to rural areas difficult.
Lack of training opportunities to experts: the data collected from managers, experts and supporting staff workers in the study area indicated that this is one of the challenges for the financial institution in lending to smallholders. According to Asiams and Osei [28], one of the major problems of the microfinance sub-sector is recruitment of effective and appropriate manpower. This they ascribed to the inability of the sector to adequately compensate personnel. Other human resource problems faced by microfinance institutions include lack of training opportunities and poor conditions of service. The quality of manpower in these institutions is reflected in the poor performance of many of them, inefficiency and high levels of frauds.

Farmers' exposure to risk: lending to smallholder farmers is not only costly but also risky. Participation in agricultural credit in the study area remains challenging for smallholder farmers because the required conditions cannot be met by the majority of them and financial institutions point out that agriculture is a risky business. This is largely because agricultural sector is considered as a high risk investment and conventional finance always aimed at reducing the risk of loan default using different mechanisms such as pledging of collateral, third-party credit guarantee, etc.

On the other hand, according to CGAP [24], formal institutions continue to view smallholder farmers as credit risks. Because, most often they are not members of associations, they have no solid track records and they have no ability to undertake viable projects.

\subsection{Econometric Analysis}

\subsubsection{Determinants of Smallholders Participation in Formal Credit}

In order to have a clear picture of the demographic, socioeconomic and institutional and communication variables which differentiate between formal credit participants from the non-participants t-test and chi-square test were applied. Five continuous and one dummy variable were found to be significant. These significant variables are presented in table 4 for continuous variables and the chi-square test for the discrete variable is described in the descriptive part above.

Diagnosis tests

In the preceding section, reports the maximum likelihood estimates of the logistic regression model. A closer look at the table reveals that most of the variables have expected sign. Diagnostic test were used to verify the reliability of the results. The Breusch-Pagan and Cook-Weisberg test reported a p_value of 0.10 , failing to reject the null hypothesis of constant variance, thereby suggesting that there was no heteroscedasticity problem in the model. Analysis of variance inflation factor (VIF) and Contingency coefficients revealed that multicollinearity was not a problem for continuous and discrete variables respectively.

A linktest shows that the model is well specified. In addition, as indicated by the goodness-of-fit (gof) test after logit regression, the null that the model is fittest is accepted at $5 \%$ significance level, suggesting that the errors in the logistic regression are logistically distributed. Therefore, 
credit participation decision of households in this case sufficiently explained by all of the independent variables.

\subsubsection{Logistic Model Analysis of Formal Credit Participation}

The maximum likelihood estimates of the logistic regression model show that age of household head (AGE), family size (FAMSIZE), experience in credit use from formal sources (EXCRIFS), total livestock ownership (LIVESTOCK), farmers perception on group formation (P GLENDING) and distance travelled by households to lending institution (DINST) were important factors influencing smallholder farmers participation in formal credit in the study area (Table 5).

Table 5. Estimation results of the logistic regression model.

\begin{tabular}{|c|c|c|c|c|c|}
\hline Dependent variable (Participation in formal credit) & Coefficient & Marginal effect & Robust Standard error & $\mathbf{Z}$ & $\mathbf{p}>\mathbf{z}$ \\
\hline Sex $($ Male $=1)$ & 0.367 & 0.0068 & 1.2207 & 0.30 & 0.763 \\
\hline \multicolumn{6}{|l|}{ Reference group (age-18 to 30 years) } \\
\hline Age- 31 to 40 & 18.489 & 0.9999 & 0.0942 & 2.46 & $0.000 * * *$ \\
\hline Age- 41 to 50 & 20.494 & 0.9999 & 3.7014 & 5.00 & $0.000 * * *$ \\
\hline Age- above 50 & 25.684 & 0.9999 & 2.8618 & 7.16 & $0.000 * * *$ \\
\hline \multicolumn{6}{|l|}{ Reference group (education- illiterate) } \\
\hline Education-primary education & 1.702 & 0.0414 & 1.9106 & 0.89 & 0.439 \\
\hline family size in number & .589 & 0.0119 & 0.3233 & 1.82 & $0.011 * *$ \\
\hline Participation in extension package (yes $=1)$ & -1.350 & -.0234 & 1.5976 & -0.85 & 0.398 \\
\hline Households perception on interest rate as a constraint (yes $=1$ ) & .064 & 0.0013 & 1.4746 & 0.07 & 0.281 \\
\hline Experience in formal credit use in years & 1.734 & 0.0351 & 0.2674 & 3.18 & $0.019 * *$ \\
\hline Land holding in hectare & -.309 & -.0063 & 1.5124 & -0.32 & 0.830 \\
\hline Total number of livestock in TLU & -.146 & -.0029 & 0.0279 & -2.15 & $0.014 * *$ \\
\hline Households perception on group lending system $($ yes $=1)$ & -2.612 & -.1057 & 1.2574 & -1.92 & $0.006^{* * *}$ \\
\hline Constant & -10.028 & & 8.8644 & -1.50 & 0.005 \\
\hline \multicolumn{6}{|l|}{ Logistic regression } \\
\hline Wald chi2 $(12)=61.79$ & \multicolumn{5}{|c|}{ Number of obs $=138$} \\
\hline Prob $>$ chi $2=0.0000$ & \multirow{2}{*}{\multicolumn{5}{|c|}{ Pseudo R2 $=0.8788$}} \\
\hline Log pseudo likelihood=-10.379421 & & & & & \\
\hline
\end{tabular}

$* * *, * *, *$ represent significance level at $1 \%, 5 \%, 10 \%$ respectively.

Source: Computed from the field survey data, 2018

\subsubsection{Interpretation of Significant Variables}

Age (AGE): The sign of this variable is consistent with that of the prior expectation and it positively and significantly influence the likelihood or the probability of farmers' participation in formal credit. Age of household head was found to be statistically significant at 1 percent significant level, indicating those older households are more likely to participate than younger one. Similar to this result Tang et al. [17] proved that old farmers are more likely to borrow than the younger farmers. This is because older farmers have more social network or social capital and thus, have more access to credit market.

Family size (FAMSIZE): According to the model result participation in formal credit positively influenced by family size at 5\% significant level and the result is consistent with the prior expectation. Other things being held constant, the marginal effect of $0.0119(1.19 \%)$ for the number of family size showed that, as the number of family size increases by 1 the probability of occurring the event (participating in formal credit) increases by $1.19 \%$.

This result is supported by Duy [18] a study in Vietnam, which found that access to credit was positively related to a larger family size.

Experience in credit use from formal credit sources (EXIFCRS): The marginal effect of this variable indicated that, other things being constant, as the household head experience in formal credit use increases by 1year the probability of households participating in formal credit increases by $3.51 \%(0.0351)$. The reason behind is that a farmer having more experience in credit use will have more tendencies towards using that source.

A study made by Tefera [29] and Tang et al. [17] also agrees with the result of this study that indicates past credit participation was a significant variable to explain participation in formal credit market. Experience makes farmers to be interested in trying out all alternatives to participate in formal credit

Total number of livestock owned (LIVESTOCK): Livestock holding as prior expectation was found to be negatively related to the probability of formal credit participation by smallholder farmers in the study area and it is significant at 5 percent significance level. The possible reasons are households with more number of livestock obtain more livestock products for direct consumption and more draft power for crop production which helps to decrease expenditures for consumption and draft power. This finding is supported by Mamo [30] and Mpiira et al. [31] in their study on determinants of participation in formal credit markets in Ethiopia and Uganda, respectively. Both found that non-participant sample households had large number of 
livestock than participants.

Perception on group lending system (P-GROUPLE): the sign of this variable is consistent with the prior expectation. It affects farmers participation negatively and significant at $1 \%$ level of significance. The marginal effect of this variable indicated that, other things being constant, the probability of participation in formal credit decreased by $0.1056(10.56 \%)$ for smallholder farmers who perceive group lending system as a constraint to participate in formal credit.

In line with this group lending scheme hinders to participate in formal credit since every individual in a group responsible to repay the loan, if loan default occurs in one of the individuals [12]. This result is also supported by kodongo and kendi [32]. In contrary to this, Mekonnen [34] and fekadu [33] concluded that group lending is the best solution for those who have no other alternative to get credit from any source individually.

Distance travelled by farmers to lending institution (DINST): This variable affects the dependent variable negatively at $1 \%$ significance level. The marginal effect of this variable indicated that, other things being constant, as walking hour of households to financial institutions increases by one hour the probability of participation of households in formal credit reduced by $0.0499(4.99 \%)$. Increase in distance from the household to credit and saving institution reduced households participation due to increased transaction costs that is farmers who reside in rural areas far from the locations of formal credit institutions have a lower opportunity of getting formal credits. This result is in lined with a study by Abdalla and Ebiaidalla [19] in kassala.

\section{Summary, Conclusion and Recommendation}

\subsection{Conclusion}

The main finding of this study was most of the smallholders use credit for non-productive activities or unintended purposes such as to cover household expenditure. Moreover, the price of crops fail at the repayment time since the repayment time is after the crops are harvested soon without giving more time to them to sell their products with fair price. Those are among the challenges individuals face in microfinance in repaying their credit and lack continuity in participating credit use from formal sources.

The other finding of this study was participation in formal credit is hard for many rural peoples. Although some improvements have been made on the challenges of access to agricultural credit from formal financial institutions, a large proportion of smallholder farmers are yet not to be reached by this institution. On the side of farmers, Poor households do not want to participate in formal financial services due to costs implication such as transaction costs, processing fee, insurance fee and proximity to financial institutions. On the other hand, Lack of awareness creation for the society on how they use credit, Lack of group borrowing experience, poor infrastructure (higher transaction cost), lack of training opportunities to experts, farmers exposure to risk are some of the challenges microfinance institutions faced in the study area to address the service to smallholders. Therefore, Successful strategies for improving participation of smallholder farmers in formal credit need to consider both the supply and demand side constraints of credit use.

\subsection{Recommendation}

After making conclusions from the research findings, the researcher made the following suggestions;

\subsubsection{To Regional Government}

From the study point of view distance from lending institution is significant factor in influencing formal credit participation of smallholder farmers in the study area. So, there is need for government to establish structures in place that can bring financial institutions much closer to the people as so as to reduce the transaction costs.

\subsubsection{To Financial Institutions}

1) The study shows that most of the clients of the institution spend their credit on non-productive activities such as to cover household expenditure. To increase participation of smallholder farmers to formal credit institutions, specialized microfinance institutions should work to improve awareness and knowledge of smallholder farmers regarding the utilization of credit. This can be done by linking the provision of loans with farmers' participation in training programs targeting all aspects of farming production. Family size with the purpose of the loan should also be considered.

2) Age of household head was a significant variable in influencing participation of smallholders in formal credit positively. So, specialized microfinance institutions should facilitate participation of middle and higher age groups in formal credit.

3) Livestock production is very important source of livelihood and a source of cash in rural areas which reduces farmers' demand and participation in formal credit through generating additional income. Therefore, attention should be given for scientific livestock management system, which is salient for the welfare of rural households. Hence, effort should be made to improve livestock genetics, provide appropriate nutrition and health service by facilitating their participation in formal credit.

4) To enhance participation of poor farmers in formal credit institutions, policies related to credit guarantees should be continuously revised to enable poor households to participate in formal credit. Alternative collateral options should be considered. For example, land-right certificates can be used. This is because most smallholder farmers live in poverty and lack adequate collateral.

5) Experience in formal credit use also a significant variable in influencing participation of smallholders in formal credit. So, microfinance institutions should give 
more emphasis to build better formal credit use experience among smallholder farmers.

\section{Direction for Future Research}

Future studies should be conducted with the objective to see whether the loan obtained from formal financial Institutions has brought about the desired growth and development to agriculture or not.

\section{References}

[1] Townsend, R. (2008). Agricultural Incentives in Africa: Policy Challenges. Washington DC.

[2] Bashir, M., Mehmood, Y. \& Hassan, S. (2010). Impact of agricultural credit on productivity of wheat crop: Evidence from Lahore, Punjab, Pakistan. Pak. J. Agri. Sci, 47, 405-409.

[3] Mpuga, P. (2010). Constraints in access to and demand for rural credit: Evidence from Uganda. African Development Review, 22, 115-148.

[4] National Bank of Ethiopia (NBE). (2017). National bank of Ethiopia quarterly bulletin. Third quarter 2016/2017 fiscal year series, Addis Ababa.

[5] Oboh, VU., and Ekpebu, ID. (2011): Determinants of formal agricultural credit allocation to the farm sector by arable crop farmers in Benue State, Nigeria. African Journal of Agricultural Research 6 (1): 181-185.

[6] Microfinance exchange market (MIX Market). (2014). Profile for ACSI. Financial data. The mix. Washington, DC2006, U.S.A. March, 2007.

[7] Mojana Wodera District Credit and Saving Institution (MWDCSI). (2017). Mojana Wodera District 2017 Annual Report: Mojana Wodera District Credit and Saving Archive.

[8] Making Finance Work for Africa. (2012). Policy brief on Agricultural Finance in Africa: Prepared by Joint African Union Commission and MFW4A task force. Tunis, Tunisia.

[9] Karlan, D., and Morduch, J. (2010). Access to Finance. In Dani Rodrik and Mark R. Rosenzweig's Hand book of Development Economics.

[10] Diana, F., and Lisa, K. (2011). Rural women's access to financial services: credit, savings and insurance: Agricultural development economics division: Working paper no. 1107.

[11] Ebisa, D. Getachew, N., and Fikadu, M. (2013). filling the breach: Microfinance. Journal of Business and Economic Management 1 (1): 010-017.

[12] Getaneh, G. (2007). Impact Assessment of Microfinance in Amhara Region of Northern Ethiopia: Moving Results into Policies and Practice Moving Results into Policies and Practice, International Conference on Rural Finance Research: FAO Headquarters Rome, Italy 19-21 March 2007.

[13] Dejene, A. (2003). Informal Financial Institution: The Economic Importance of Iddir, Iqqub, and Loans, Proceedings of the National Workshop on Technological Progress in Ethiopia, Agriculture, Nov. 20-30, 2001, AAU, Addis Ababa.
[14] Hussein, H. (2007). Farm Household Economic Behavior in Imperfect Financial Markets. Doctoral Thesis, Swedish University of Agricultural Sciences, Uppsala.

[15] Shah, S., Hashmi, A., and Bukhari, A. (2008). Determination of Credit Programme Participation and Socioeconomic Characteristics of Beneficiaries: Evidence from Sargodha. The Pakistan Institute of Development Economics, 2008.

[16] Gunnar, T. (2010). Regulating for legitimacy: Consumer credit access in France and America: Harvard business school.

[17] Tang, S., Guan, Z., and Jin, S. (2010). Formal and informal credit markets and rural credit demand, in china: Paper prepared for presentation at the Agricultural \& Applied Economics Association. AAEA, CAES, \& WAEA Joint Annual Meeting, Denver, Colorado.

[18] Duy, V. (2012). Determinants of household access to formal credit in the rural areas of the Mekong Delta, Vietnam. MPRA Paper No. 38202.

[19] Abdalla, E., and Ebaidalla, E. (2015). Determinants of small farmers access to formal credit institutions in Kassala state, East Sudan: Determinants and Possible Ways Forward, University of Kassala Journal, third issue, September 2015.

[20] Lighton, D., Tatenda, M., and May, M. (2015). Determinants of Access to Formal Credit by Smallholder Tobacco Farmers in Makoni District, Zimbabwe. Greener Journal of Agricultural Sciences Vol. 5 (1), 034-042.

[21] Ali, D. A., and Deininger, K. (2012). Causes and implications of credit rationing in rural Ethiopia: The importance of spatial variation. Policy Research Working Paper, No. 6096, World Bank, Washington DC.

[22] Yemane, T. (1967). Statistics, an introductory analysis, 2nd edition, newyork: Harper and Row.

[23] Hosmer, D., \& Lemeshow, S. (2000). Applied logistic regression. 3rd Edition. A Wiley-Inter science Publication. New York.

[24] Consultant group to assist the poor (CGAP). (2005). Mozambique Agricultural Microfinance: An Overview. The Challenge of Agricultural Lending, Case Study No. 1. August.

[25] Musyimi, J. (2010). Assessing Credit Access by Bee-keeping Farmers in Mwingi District. Technical Report. Nairobi: ASARECA.

[26] Zeller, M., Sharma, M., Ahmed, A., and Rashid, S. (2001). Group Based Financial Institutions for the Rural Poor in Bangladesh. An Institutional and Household Level Analysis. International Food Policy Research Institute. Washington D.C. Research Report 120.

[27] Befekadu, K. (2007). Outreach and financial performance analysis of microfinance institutions in Ethiopia: African economic conference United Nations conference center, Addis Ababa, Ethiopia.

[28] Asiama, P., and Osei, V., (2007). Microfinance in Ghana: an overview. Research Department Bank of Ghana, Economic Web Institute.

[29] Tefera, D. (2004). Determinants of smallholder farmers demand for non-formal credit. The case of Farta woreda. Unpublished M. Sc. Thesis. Alemaya University. 
[30] Mamo, G. (2015). Determinants of Formal Credit Market Participation by Rural Farm Households: Micro-level evidence from Ethiopia. Paper for presentation at the 13th International Conference on the Ethiopian Economy. Ethiopian Economic Association (EEA) Conference Centre, Addis Ababa, Ethiopia, July 23-25, 2015.

[31] Mpiira, s., Kiiza, B., Katungi, E., Staver, C., Tabuti, J., Kyotalimye, M., Muwumba, P., Karamura, E., and Tushemereirwe, W. (2013). Factors influencing households' participation in the Savings and Credit Cooperative (SACCO) programs in Uganda. African Journal of Agricultural Research, Vol. 8 (43), pp. 5280-5288.
[32] Kodongo, O., and kendi, L. (2013). Individual lending versus group lending: an evaluation with Kenyas microfinance data. Review of development finance, 3 (2013), 99-108.

[33] Mekonnen, Y. (2008). MFI-bank financial linkage: ACSI's experience and future trends, East Africa Sub regional Workshop, Bahirdar.

[34] Fekadu, Y. (2011). Outreach services and sustainability: the case of Amhara credit and saving institution. Unpublished M. Sc. Thesis. Addis Ababa University, Ethiopia. 